\title{
SOME INTERLINGUISTIC RELATIONSHIPS IN THE FIRST HUNGARIAN PROVERB COLLECTION OF 1598
}

\author{
Gyula Paczolay
}

\begin{abstract}
Following a short historical introduction, referring to more than a thousand Hungarian students studying at Wittenberg and other universities in the 16th century, the article presents proverbs included in the first 1598 Hungarian collection, which was compiled by the Strasburg graduate schoolmaster János Baranyai Decsi and was based on the 1574 edition of Adagiorum Chiliades by Erasmus, and others. It includes universal proverbs like "What isn't good for you, isn't good for others", European loan proverbs originating in the Greek classics, like "To keep a snake in the bosom" (Aesop), from Roman classics, like "To carry wood to the forest" (Horace), "Cobbler do not go beyond your last" (Pliny the Elder), "Go slowly, you arrive earlier" (Suetonius), proverbs from the Bible "He digs a pit for others and falls in himself" (Proverbs 26: 27) - "You see a splinter in another's eye, but fail to see a beam in your own" (Matthew 7: 3). From Medieval Latin there is, for example, "One need not inspect the tooth of a gift horse", "Where a pig is offered, be there with your bag", "Where there are three women, there is a market." There are also some Hungarian variants of European proverbs. Regional and sub-regional proverbs include those having Nordic (Slavonic, Baltic) affiliations, like "Peel the lime tree until it peels". "A cheap meat has a dilute broth" has Northern and Southern Slavonic, Baltic and Turkish equivalents (meat is replaced by fish in Estonian, Finnish, Zyryan and Ukrainian), "One stone is enough [to frighten] one thousand crows" can be found in Bulgarian, Turkish and Persian. "One sitting among the reeds can make a whistle of his choice" and "It does (not) bring much to the kitchen" have earlier exact German equivalents, while "A liar is caught sooner than a lame man" is found in different Romance languages. There are a number of proverbs found only in Hungarian, like "The pepper is small but "strong", "A Székely picks up anything of more value than a louse", "He that wants to shoot a crow, does not bang his bow", "There is no packed hay-cart unable to carry one more forkful of hay", etc.
\end{abstract}

Key words: Bible, Balkan, Decsi, Erasmus, European, German, Greek, history, Hungarian, Italian, Latin, origins, proverbs, Slavonic, Turkish

\section{INTRODUCTION}

It is well known that in studying the linguistic affiliations of the proverb lore of any European language the following categories can be distinguished:

1. Loan proverbs that exist in many or several languages. They include universal proverbs, also known in different cultures outside Europe, Euro- 
pean proverbs present in several languages in all the geographic regions of the continent, regional proverbs found in special regions, and subregional proverbs found in certain parts of a region. Sometimes, local variants of European proverbs are also encountered.

2. Indigenous proverbs that are found only in the language studied, and sometimes appearing later as loan proverbs in a "neighbouring" language.

In this study the interlinguistic relationships of proverbs in the first Hungarian proverb collection have been investigated. The book by János Baranyai Decsi, the Strasburg graduate, Hungarian schoolmaster in Székelyvásárhely (now Marosvásárhely in Transylvania, Romania), fluent in Latin, Greek and German, was published in Bártfa (now in Slovakia) in 1598.

\section{THE HUNGARIAN LANGUAGE UNDER DIFFERENT INFLUENCES IN THE CARPATHIAN BASIN}

The Hungarians - coming from the East - having been previously in contact with peoples speaking Turkic (Chuvash) and Iranian languages, settled in the Carpathian basin at the end of the 9th century AD - They found there some Slavonic population and Slavonic neighbours in the north and south and Germans in the west, where the languge of the court, church, administration and schools was Latin. They soon adopted Western Christianity, the first King, St Stephen received a crown from the Pope and his wife was a Bavarian princess Giselle, with whom Bavarian priests and soldiers came to the country. It is known that prior to the Reformation, Hungarian students studied at the universities of Bologna, Paris, and Vienna, and in the second half of the 16th century about one thousand Hungarian students - future teachers and Protestant priests - studied at the University of Wittenberg alone. During the years spent in German-speaking areas they had learned to speak German, too. Returning to Hungary and Transylvania they brought home many books in Latin and German including copies of Adagiorum Chiliades by Erasmus (Er.Ad.).

Contacts were maintained with Byzantium in the south and with the Slavonic neighbours as well, resulting in a considerable number of Slavonic loan words in Hungarian (KI). There were also dynastic, family connections with the Kiev court and many young Hungarians attended the Cracow University and, no doubt, a number of them learned also Polish.

The German cultural influence was partly interrupted in the central area occupied by the Turks in the 16 th century for about 150 years. Hungarians in contact with the Turkish authorities mastered the Turkish language; some 
Turkish words became well-known loan words in Hungarian. Turkish words and perhaps some proverbs, too - emerged in the Hungarian via Southern Slavonic languages. During this period the German-Latin influence continued in the unoccupied western and northern part of the country. In the unoccupied Eastern part, Transylvania, the role of Latin was partly taken over by the Hungarian.

After the defeat of the Turks, the Latin-German influence continued with a decreasing momentum until 1945. The following Russian occupation, lasting for 45 years, had little effect on the Hungarian language. Now some English loan words and also translations of some English proverbs, e.g., "The proof of the pudding is in the eating" as "A puding próbája az evés" and "There is no such thing as a free lunch" as "Nincs ingyen ebéd" have appeared. (The first recording of "Time is money" [Benjamin Franklin 1793] in Hungarian - "Az idő pénz" - dates back to 1842 .)

\section{JÁNOS BARANYAI DECSI AND HIS PROVERB COLLECTION}

János Baranyai Decsi (Ioannes Decius Baronius, Fig.1, see p. 65) was born in about 1560 in Decs, then Baranya County, Southern Hungary, under the Turkish rule. He attended the colleges of Tolna (under the Turkish rule), Debrecen and Kolozsvár (in Transylvania), then studied at the Wittenberg University and wrote a thesis on certain chapters of Aristotelean philosophy at the Strasburg Academy under the guidance of Professor Johann Ludwig Hawenreuter. (This was published in Strasburg in 1591 and in Wittenberg in 1595.) He wrote Latin and Greek poems and authored one of the first Latin travel descriptions, written by a Hungarian on a long journey from Bonchida in Transylvania via Lwów, Warsaw, Danzig and Berlin to Wittenberg (1587). He is the author of the first book presenting a detailed comparison of Hungarian and Western European law (1593); he made the first translation of a Latin classic into Hungarian (Sallust) (1596), and also wrote about the history of Hungary of his age that was published only in the 19th century.

His proverb collection entitled Adagiorum græcolatinoungaricorvm chiliades quinque (in short: Adagiorum, BD) (Fig. 2, see p. 65) was published by the Bártfa printer Iacobus Klöß in 1598. It includes 4,795 (Greek-) Latin-Hungarian items, among them about 900 proverbs. His source and model was a volume of Adagiorum Chiliades (Er.Ad.), a 1574 Basel edition of 16th-century proverbs and phrases including collections of Erasmus, Hadrianus Iunius, Gilbertus Cognatus, Ioannes Alexandrus and others (Fig. 3, see p. 65). Decsi made a selection of this stock but only a part of them was translated into Hungarian; 
he often gave as equivalent the corresponding Hungarian phrase of the same or similar meaning and different wording. His collection includes also proverbs found in earlier works of 16th-century authors, e.g., in the Hundred Fables of Aesop by Gáspár Heltai (1566, HGF) (Fig. 4) and in letters, too. It is divided into chilias, centurias, and decas, with items inside a decas being also numbered. As a rule, the Greek version stands first (it is sometimes missing), followed by the Latin and Hungarian ones. Authors are not referred to and explanations - like those found in the collection of Erasmus (Er.Ad.) - are not included (Fig. 5, see p. 66) (PGy-7).

\section{INTERLINGUISTIC RELATIONSHIPS IN DECSI'S COLLECTION}

Decsi's collection includes universal, European, European regional and subregional proverbs (PGy-8), Hungarian proverbs unrelated to those in other languages, and also simple phrases and words, remaining outside the scope of this study.

3.1. Universal proverbs are found in different cultures, also in European and Oriental languages, expressing simple common observations and ethical norms (PGy-2: 11-21). The Decsi collection includes universal proverbs, like "Where there is fire, there is smoke" - Ahol füst, ott tüz. Flamma fumo est proxima. (BD-1.4.1.1.), known in 54 European and 5 Oriental languages (PGy-2.1.1.3., PGy-3.1.), and “What isn't good for you, isn't good for others" Az mi néked nem ió, másnak sem ió az. Alteri ne feceris, quod tibi fieri non vis. (BD-5.4.4.4.), known in 40 European and five Oriental languages (PGy-2.1.3.1., PGy-3.57).

3.2. European proverbs are known in 28 to 54 languages out of the 55 considered ones (PGy-3). They are certainly loan proverbs in Hungarian, originating in the Greek and Latin classics and Medieval Latin, transmitted by the Latin quotations of Erasmus and others. (These classics were translated into Hungarian only later.) Another source is the Bible, the Old Testament having been written originally in Hebrew and the New Testament in Greek (Koine).

Manuscript translations of parts of the Bible into Hungarian are known from 1416 on. The New Testament was published in 1541 (Fig. 6, see p. 66), a nearly complete translation, published in parts by Gáspár Heltai, a priest of Kolozsvár (whose mother tongue was German and mastered the Hungarian language later), was printed between 1551 and 1556, a complete translation by Gáspár Károlyi appeared in Vizsoly in 1590 (Fig. 7, see p. 67). The Hungarian translators have used the Hebrew and Koine texts, and likely the Vulgate, the 


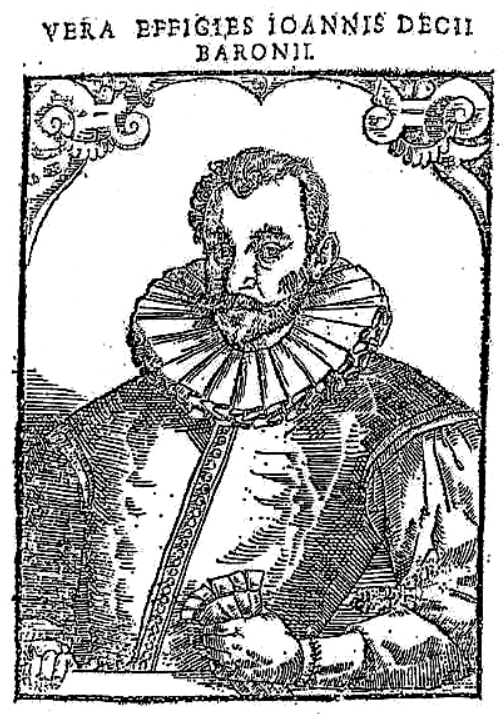

Goarres spciüs

Figure 1. János Baranyai Decsi (c 1560-1601) and his signature.

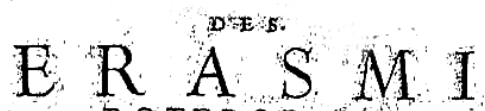

ROTERODANI

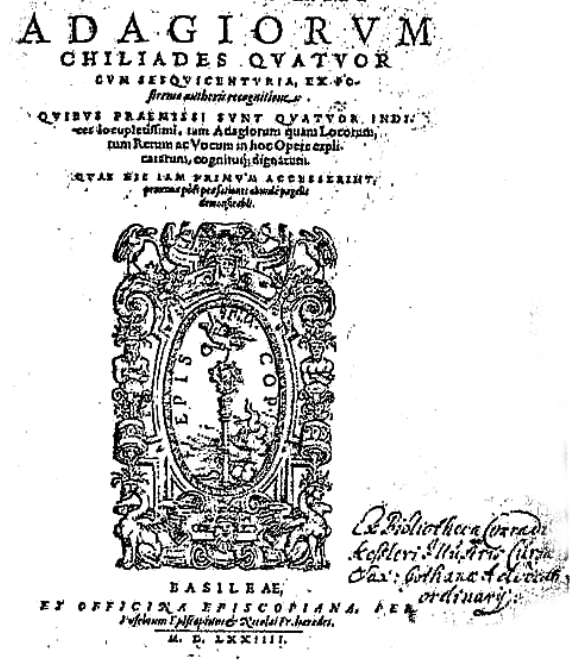

Figure 3. The Adagiorvm of Erasmus et al. (1574) used by Decsi.

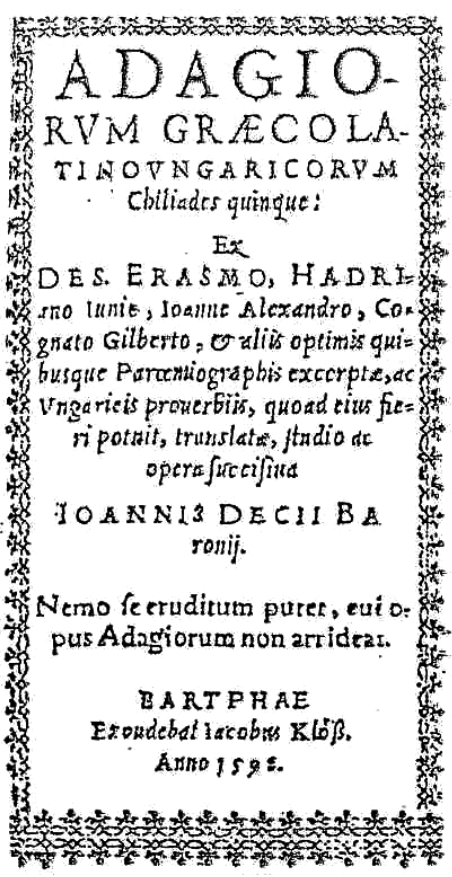

Figure 2. The proverb collection of Decsi (1598).

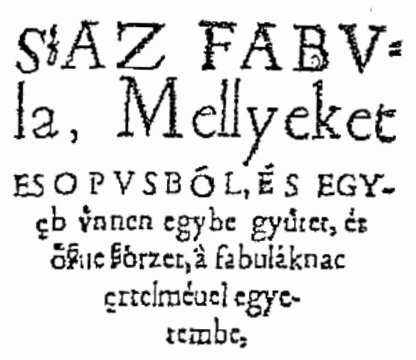

HELTAI G SPAR:

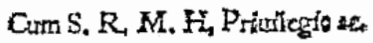

$\frac{\operatorname{COLOSVAROI}}{1.5 .6 .6 .}$

Figure 4. Fables of Aesop in Hungarian, by Gáspár Heltai. (1566) 
55\% CHILIEDIS IT

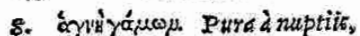
Am lád, ki mir mondhatna hozet,

6. Rbeginis timidior: Nékiis hituán he lyen sll vgyanaz: sớue.

Io. Inertiwh chorus, Heuolkodák gyålef,

CHILIADIS SECVN. D.AE CENTVRIAIX.

DECAS X.

I. Rapmorerum Cimari, Ebưl gyõitet Éerdékntk, ebúl kel el vezni.

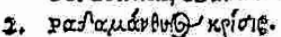
Rbadamanthi iudiciush, Igaz irelet.

3. Rhadanentbi iufierendum Igaz. eskéués.

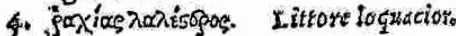
Elég czáczogó.

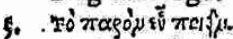
Prafentem forturam bori confule,

6. lob má egy veréb, hogy nea nim hólnap egy tuzolk.

Qui in ontrite atoge in omnitemporte Onni laude yasat, is onniun deteritinas eft. Nincz oly hicuan ember $x_{2}$ kiben valami iólág ne legyen.

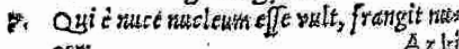
6em:

Figure 5. Page 158 of Decsi's collection.

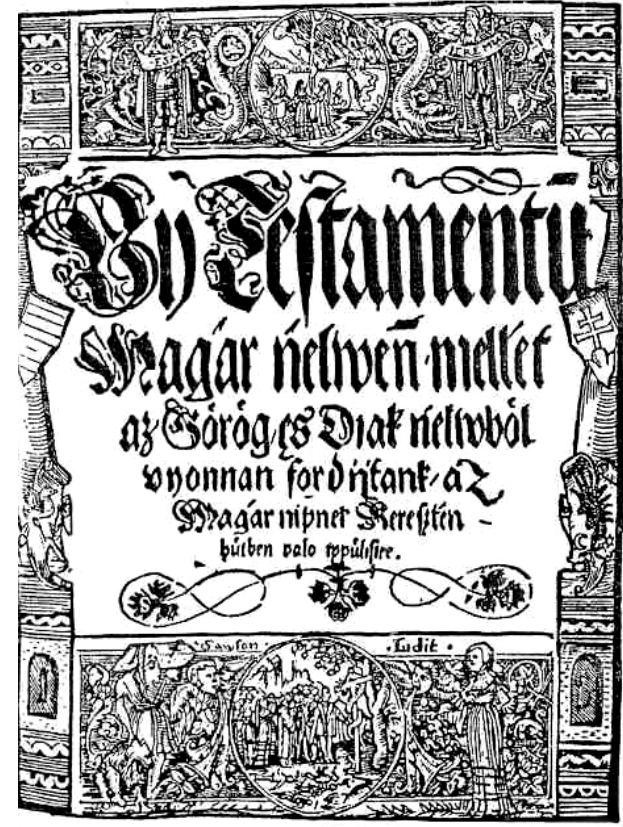

Figure 6. Hungarian New Testament (1541).

Latin translation by St Jerome in the 7th century, and the German translation by Martin Luther (1534) as well. Quotations from the Bible by the priests have certainly contributed to their folklorization and becoming later genuine proverbs.

According to the origins of the proverbs, different categories can be established. Some examples are presented together with their English translations and references to their appearance in the Adagiorum (BD). A number of proverbs appear several times, but as a rule only one occurrence is quoted. The data on the individual classical authors and their works have been taken from other sources (AA, ODEP, SzGy-1).

3.2.1. Greek classics. Kigyót tartani kebelében. - To keep a snake in his bosom.

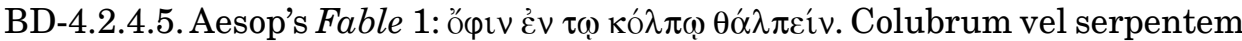
in sinu fouere. - Minden köuet mozgatni. - To move all the stones. "To leave

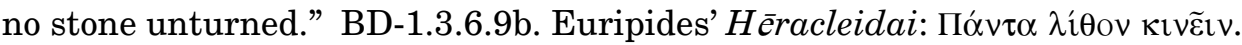
Omnem mouere lapidem.

3.2.2. Latin classics. Erdöre vinni fát. - To carry wood to the forest. BD1.5.10.10. Horatius' Satirae 1.10, 34: In sylva ligna ferre (SzGy-1.415.) - Nem 
ió az darast ßurkálni. It is not good to poke at a wasp. BD-1.7.4.4. Plautus' Amphitruo II.2: Irritare crabrones. - Közelb az ing az czuhánál. The shirt is closer [to the body] than the coat. BD-1.1.9.6. Plautus' Trinummus V.2.30: Tunica propior pallio est (AA-202). Er. Ad.: Frons occipitio prior. - Ne fellyeb varga az kaptánál. - Cobbler do not go above [i.e. beyond] the last. BD1.4.8.10. Pliny the Elder's Naturalis Historia 35.10.85: Ne supra crepidam sutor iudicet. Er.Ad. 1.6.16: Ne sutor ultra crepidam. (AA-268) (In 29 languages: PGy-3.105) - Czak azt hüd az kit ßömöduel látz. Believe only what you see with your eyes. BD-1.1.7.9. Seneca's Epistolae VI.5: Homines amplius oculis, quam auribus credunt. Er.Ad.: Oculis magis habenda fides quam auribus. - Lassan iáry s hamaréb el érz. -

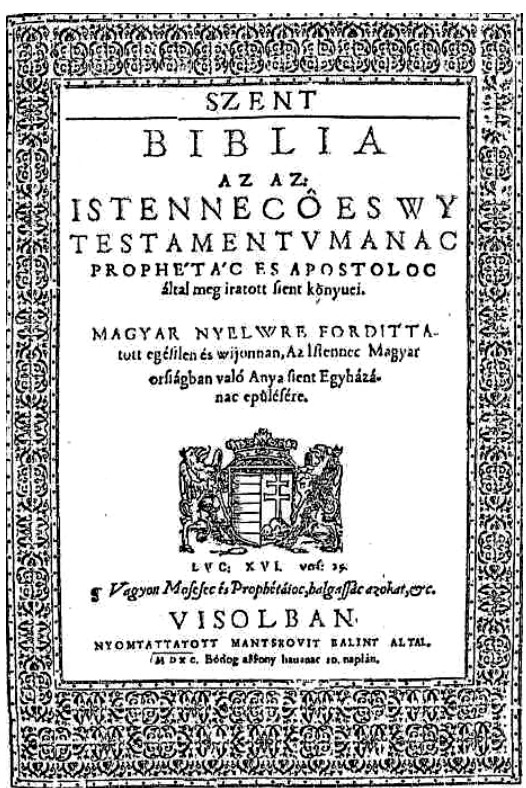

Figure 7. The Hungarian "Vizsoly" Bible (1590). Go slowly and you arrive sooner. BD-

2.1.1.1. Suetonius' De vita Caesarum. Augustus 2.25: Festina lente. (AA-545) Czak ßörit veti el à farkas, nem terméßetit. - The wolf discards its hair but not its nature. BD-3.3.2.2. Suetonius' De vita Caesarum. Vespasianus 16:Vulpem pilum mutare, non mentes. Er. Ad.: Lupus pilum mutat, non mentem. - A hól farkast emlegetnek kert alat kullog. - Where a wolf is mentioned, it walks round the garden. BD-2.7.9.3. Terentius' Adelphoe IV.1.21: Lupus in fabula (AA-718).

3.2.3. Bible. The Latin quotations are the corresponding texts of the Vulgate.

Old Testament - Nem illik diznó orrába az arany peretz. A golden ring is not fitting in the snout of a pig. BD-1.3.7.5. Proverbs 11:22: Circulus aureus in naribus suis. - Másnak ass vermet $\mathrm{s}$ ö maga esik bele. - He digs a pit for others and falls himself into it. Proverbs 26:27: Qui fodit foveam, incidit in eam. Also in Psalms 9:16, Jesus Sirach 27:28, Ovid's Ars amatoria, etc. (In 49 languages with equivalents in Arabic and Persian, PGy-3.9.)

Hallád, czak annijra nyuitozál, az mîg az lepel ér. - Listen [to me], stretch yourself only as far as the cover reaches. BD-4.4.8.9. Isaiah 28:20: Coangustatum est enim stratum, ita ut alter decidat; et pallium breve utrumque oprire non potest. (In 42 languages, including equivalents in Arabic, Persian, etc., PGy3.50.) 
New Testament - Az ßálkát más ember ßömében meg látod, az gerendát penig az magadéban nem látod. - You see the splinter in the eye of others, but fail to see the beam in your own. BD-1.5.5.2. Quid autem vides festucam in oculo fratris tui et trabem in oculo tuo non vides. Matthew 7:3 - Luke 6:41. (In 47 languages, PGy-3.20.)

Ki mit keres meg leli. - What one seeks, finds. BD-1.1.4.9. Matthew 7:8: Qui quaerit, invenit... (PGy-1.294).

Ha Isten velünk: senki ellenünk. - If God is with us, nobody is against us. BD-3.9.7.10. Romans 8:31: Si Deus pro nobis, quis contra nos? (PGy-1.252.)

Az ki mint vet, vgy àrat. - As one sows, so he reaps. BD-1.6.9.8. Galatians 6:7: Quae enim seminaverit homo haec et metet. (Also in Cicero's De oratore 2.65.261: Ut sementem feceris, ita et metes.) (In 52 languages, PGy-3.2.)

3.2.4. Medieval Latin. Aiándék lónak nem kel à fogát nézni. - One need not inspect the tooth of a gift horse. BD-4.4.9.6. St Jerome: Noli equi dentes inspicere donati. (AA-426) - Er.Ad.: Non oportet equi dentes inspicere. (In 48 languages: PGy-3.5.) - A hól három aßßony ember vagyon, sokadalom léßen ott. - Where there are three women, there will be a market. BD-5.7.5.6. Tres mulieres nundinas faciunt. - Tres mulieres faciunt nundinas. (AA-444, PGy1.32.)

Az mely ebet meg akarnak ölni, annak dühös nevét költik. - The dog intended to be killed is said to be rabid. BD-1.7.1.6. Dum canum cædimus corrosisse dicitur corium - Az harist az ö maga nyeluén fogiák meg. - The corncrake is caught, following its tongue [i.e., voice] BD-1.3.1.2b Suo ipsius canto periit sorex. - Az kit Isten meg akar verni, elößöris eßét veßi annak. Whom God intends to punish, first takes away his sense. BD-4.6.9.7. Publilius Syrus: Quos Deus perdere vult, dementat prius. (PGy-1.255.)

Hituán madár az, az ki az ö maga fézkét meg rútittia. - It is bad bird that soils its own nest. BD-4.2.4.3. Turpis avis proprium qui fodat stercore nidum. (In 28 languages: PGy-3.106) - A hól malatzot igérnek, sákoddal ott légy. Where a pig is promised, be there with your bag. - BD-4.5.7.2. Saccus adaptetur, porcellus cum tibi detur. (AA-674) - Nehéz az àgh rókát az törbe eyteni. - It is difficult to catch an old fox in a trap. BD-1.8.1.3. Annosa vulpes haud capitur laqueo. (PGy-1.476.)

Nem egy vágásval esik le az tölgy fa. An oak tree is not felled by one stroke. BD-1.1.8.10. Multis ictibus dejicitur quercus. (Er.Ad.:1.8.94) - Non annosa uno quercus deciditur ictu. Palingenius' Zodiacus Vitae XII.459 (AA-26, PGy-1.132) - Hiuatlan vendégnek aytó meget helye. - The place of an uninvited guest is behind the door. BD-1.2.5.3. Retro sedet ianuam non invitatus ad aulam. (In 44 languages, PGy-3.39.) 
3.2.5. Hungarian variants. In some cases, Hungarian variants of European proverbs do appear. For example, the medieval proverb: Ignarus rediit Romam deductus asellus. - An ass led to Rome returns as an ignorant - is known in 36 languages (PGy-3.87) with different place names, like Oxford, Paris, Rome, Salamanca, etc. In Decsi's collection it appears as "Az ökör vgyan ökör ha ßinte Béczbe haitiák is." - An ox remains an ox, even if it's driven to Vienna. BD2.8.7.2. (The text is based on the fact that a number of Hungarian students studied at Vienna University.) - Similarly the "Tengerbe visz vizet." - He carries water into the ocean. - BD-1.1.8.8. has changed in time into "Dunába hordja a vizet." (He carries water into the Danube.)(PGy-1.621, VG-2.343/188.)

3.3. Regional proverbs. A number of proverbs in Decsi's collection are regional proverbs. In most cases, it is difficult to establish the original language and only the date of the first known recording is available. Most often, the Hungarian text is the first; sometimes a Czech or a Polish one precedes it. In general, in these cases the Latin text given by Decsi, taken from Erasmus or another contemporary source has the same general meaning but a very different wording. (Some examples have been presented below.)

3.3.1. Northern (Slavonic, Baltic) affiliations. Ne hány borsót az falra. Do not throw peas against the wall. BD-4.7.4.6. and Czak ollyã mint ha borsót öntenének az falra. - It is as if peas would be thrown against the wall. BD4.9.6.4. (Czech, Ukrainian, Polish, Russian) (PGy-4.39/2) - Eßes diznó mely/ mély gyüköret ránta. - It's a clever pig that extracts a deep root. - BD-3.6.1.3. (Belarusian, Czech, Estonian, Latvian, Lithuanian, Polish, Russian, Slovak, Ukrainian)(AK-3.492/46, CF-271, GK-252, PGy-4.40/5).

Addîg hámcz az hárs fát, mîg hámlik. - Peel the lime tree, until it peels. i.e., Strike the iron while it is hot. BD-3.4.1.10 (Belarusian, Czech, Latvian, Lithuanian, Polish, Ukrainian)(PGy-6).

Még az Istenis ki tér vólt az réßeg ember elöt. Even God gives way to a drunken man. BD-3.6.4.10. Czech: Opilému člověku se i Pán Bůh z cesty vyhne. CF-172, Slovak: Opitému i Kristus Pán z cestu vystúpil. (ZA-105/363.)

$\mathrm{Az}$ ketske sem meñe az vasárra, de czapiák hátúl. (Even the goat would not go to the market, but it's beaten from behind.) BD-3.8.6.5. (Czech, Polish: Nierada koza na targ, ale musi. [1590] AK-3.507/9, Russian, Slovak,Ukrainian.) (CF-341, PGy-4.40/5)

\subsubsection{Northern and southern (Slavonic, Balkan, Turkish) affiliations.}

Szemérmes Deáknak üres táskáia. - A shy teacher has empty scrip. - BD3.6.7.9. (Czech: Studlivý žebrak, prázdná kapsa. CF-152, Slovak - Bulgarian, Serb) (PGy-9) 
Nem kel az halottat az Szentegyháztól haza vinni. - The dead should not be taken back from the church to his home. BD-1.3.5.10. (Czech, Russian, Slovak, Ukrainian-Bulgarian, Turkish.) The Latin text in Ad., Non est fumus ex cœmeterio reducendum, is likely a literal translation from Hungarian by Decsi, as it is not found in Er.Ad. (PGy-9)

Olczó húsnak hig az leue - A cheap meat has a dilute broth. BD-2.8.4.7. (Czech, Slovak, - CF-331 - Bulgarian, Serb, Turkish). Its variant including fish instead of meat: Cheremis, Estonian (Odav kala, lahja leem. KS-7759), Finnish (KM-438), Russian, Ukrainian and Zyryan (PGy-1.232); "Cheap meat is eaten by the dogs" is found in Belarusian, Bulgarian, Lithuanian, Polish and Ukrainian (PGy-9).

Némának annya sem érti ßauát. - A dumb person's - later: child's - word is not understood even by his mother. - BD-2.1.3.4. (Belarusian, Czech CF-16, Lithuanian, Polish, Russian, Ukrainian - Albanian, Bulgarian, Slovenian Azeri, Chuvash, Crimean Tatar, Gagauz, Karachai-Balkar, Karaim, Karakalpak, Kumyk, Nogai, Tatar, Turkish, Turkmen, Uzbek. (BU-3,4, CF-16, YM-25/1 PGy4.40/4)

Ió pap hóltîg tanúl. - A good priest learns until his death. BD-1.6.8.3. (Czech [Dobrý kněz vždy se učí.], Slovak, Bulgarian, Serb, Slovenian, Turkish)(CF264, PGy-3.31.).

Az ki másnak ßekere farkán ül, annak énekét mondgya. - He that sits on the tail of somebody else's cart, sings his - i.e., the owner's - song. BD-4.9.8.2. (Czech, Polish - AK-2.916/2,1590 - Russian, Ukrainian-Bulgarian, Croatian, Serb, Turkish-Azeri, Bashkir, Chuvash, Karaimi, Tatar)(BU-1048, PGy-9).

Iob mà egy veréb, hogy nem hólnap egy túzok. - Better a sparrow (i.e., a little bird) today, than a bustard 'Otis' (i.e., a big bird) tomorrow. - Equivalents including different small and big birds. Slovak, Ukrainian, Croatian, Slovenian, Turkish (PGy-3.34). This proverb was also recorded among Romanians living in Hungary (PGy-4.45/3).

Lassu viz partot moss. - Slow waters wash away the bank. (Magis nocent insidiæ quæ latent.) BD-5.3.2.3. (Belarusian, Czech, Lithuanian, Polish, Russian, Slovak, Ukrainian-Bulgarian, Croatian, Serb, Slovenian, Turkish (PGy3.78.).

\subsubsection{Southern (Slavonic, Turkish) affiliations.}

Nem fog az aranyon az rosda. - Rust does not affect gold. BD-4.1.6.6. (Bulgarian: Златото го рьжда не яде. - Serb. IN-751).

Hires eperre nem kel kosárual menni. (Partiurũt montes, nascetur ridiculus mus.) - One need not take a basket to collect famous strawberries. - BD- 
1.7.2.10. (Albanian, Serb, Slovenian [strawberry], Romanian [fruit], Greek, Turkish: Üzümü bol işittiğin bağa sepetini küçük götür. [grapes])(IN-505, 1317, 1916, 2521, PGy-4.42/2, PGy-6.200/3.3. YM-20/2).

Elég egy kö ßáz variúnakis. - One stone is sufficient for hundred crows [to frighten them]. - BD-5.6.10.3. (Bulgarian, Turkish [Bin kargaya bir sapan taşı yeter.], Persian [clot]) (PGy-4.43/7, YM-141/1).

Nem indúl meg nád ßál fuás nélkül. - The reed does not start [to move] without blowing. BD-1.4.9.6. (Bulgarian, Slovenian, Turkish)(IN-551, PGy-5.201/ 3.7.).

Soha ne keres ökör alat boriút. - Never look for a calf under an ox. - BD2.7.5.10. - Még az ökör alatis boriút keres. - He looks for a calf even under an ox. - BD-4.4.1.8. (Bulgarian, Serb)(PGy-9).

Addîg iár ám az tök az iégre, hogy bé törik egyßör az feie. - The pumpkin is going to the ice, until its head once breaks. - BD-1.8.5.2. (Albanian, Bulgarian, Croatian, Romanian, Serb) (IN-657, PGy-3.55).

\subsubsection{Other affiliations.}

Earlier German occurrences are available for the following proverbs:

Semmit nem hoz az az konyhára. - It does not bring anything to the kitchen. (i.e., it is of no use.) - BD-3.2.9.6. (Quid ad Mercurium?) 3.6.1.5. (Quid ad farinas?) Meinen sie haben dessen macht das allein ein gewin darbey sey vnd in die Küchen trag. (Aventinus Johannes' Chronica Bavaria. 1567)(AJ-412v). - Das bringt was/wenig in die Küche. (RL-896/2, WF-2.1884).

Az ki nád közöt üll, Bintén ollyan sipot czinál az minemüt akar. - One sitting in the reeds can make a whistle he likes. BD-1.3.3.2. (Pecuniæ obediunt omnia.) In the collection of Sebastian Franck (1541): Der in rorn sitzt, schneidt jm. selbst pfeiffen wie er will (SF-86v), exactly corresponding to the Hungarian text, unlike the Latin one in BD.

Italian and French sources are available for the following proverb: Hamaréb meg érnek egy hazug embert, hogy sem egy sánta embert. - A lying man can be caught sooner than a lame man. BD-2.3.6.7. (Quintilian: Mendacem memorem esse oportet.) - Exact equivalents of it can be found in the following languages: Portuguese, Spanish, Catalan, Old French, Italian (Si giunge più presto un bugiardo che un zoppo.), Tuscan, Piemontese, Bolognese, Rhaeto-Romanic (RD2.62). Later a Hungarian variant involving a lame dog (sánta kutya) became and is now well known (VG-1.123/225, quoting 211 data). Another variant: Lies have short legs (ODEP-461/1 is known in several European languages (RD2.62 , ŚŚK-330). 


\subsection{Hungarian proverbs with no affiliation.}

The proverbs in this chapter are related to Hungarian events, places or persons or simply have no established affiliation to a proverb in another language. In some cases it is likely that a closely equivalent proverb of later recording in a "neighbouring" language is, in fact, a loan proverb from the Hungarian.

\subsubsection{Proverbs related to Hungarian events, places, persons.}

Meße Buda sánta embernek. - Buda is far for a lame man. BD-2.5.3.3. (The Latin text 'Procul Buda claudo' is not found in Er.Ad, it is likely a translation into Latin by Decsi.) - Te sem vagy iob az Déákné váznánál. - Even you are not better than the linen of the teacher's wife. BD-3.4.4.3. - Oly gyalázat, hogy az Dúna sem mossa el. - It is such a shame that even the Danube cannot wash it away. BD-3.7.10.7. (Tinctura Cyzicerna.) - Nagy dolog vólna, ha az Dunában nem vólna víz. - No water in the Danube, it would be a remarkable event. BD1.6.1.2.

Igen túd Haydu harangot önteni. - A Haydu [foot soldier in the 16th century] is an expert in bell-founding. (Ironical) BD-1.3.7.2. - Vgy sétál mint az kúnok ebe az homokon. - He walks like the dog of the Cumans on the sand. BD-2.2.6.9. - Teis magyar módra meg vér az esö $\mathrm{s}$ vgy veßed reiád az köpeneget. - You too - Hungarian style - take the raincoat, after having been soaked by rain. BD-5.5.4.2. - Oly meßße vagy tölle, mint Mako Ierusalemtöl. - You are as far from it as Makó (in Hungary) is from Jerusalem. BD-1.1.4.8. - Külömb azért Máthias kiraly, s Máthiás kouácz. - King Matthias and Matthias the Smith are different persons. BD-2.4.4.2. (Mysorum \& Phrygum termini discreti sunt.) - Nò mind fel veßi az Székely, valami egy tetünél iob. - The Székely [Hungarian inhabitant in South-Eastern Transylvania] picks up anything of more value than a louse. BD-2.4.10.4. - Az Székely pokolbais el megyen, czak fizessenek néki. - The Székely will go even to Hell, if he is [properly] paid for it. BD3.5.6.10. - Székely fortély. - Székely's cunning. BD-2.3.5.5.

\subsubsection{Other Hungarian proverbs.}

Küczin az bòrs, de erös. - The pepper is small but hot. BD-3.8.8.8. (Tydæus corpore, at Hercules.) - Az Christus koporsóiát sem örzik heiában. - Even Christ's coffin is not guarded for no payment. (Lingua seorsum inciditur.) BD3.6.10.4. (A recording of it in Slovak from 1938 is known. PGy-4.45/2) - Diznóra gyömbért ne vezteges. - Do not waste ginger on a pig. BD-1.8.10.2. - Nám oly kevély, mint ha öué volna az dió fáîg. - He is as proud, as if everything up to the walnut tree would be his. BD-2.8.2.6. 
Még az ebnek sem ió az elsö fia. - Even in case of a dog, the first "son" isn't a good one. BD-5.1.2.3. (Posteriores prioribus sunt potiores.) - Nagy fába vágta az feißét. - He has struck his axe into a big tree. BD-1.1.5.3. - Szemérem az futás, de haznos. - To run away is a shame, but it's useful. BD-1.8.3.4. - Igen illik, mint az bot az tegezbe. - It fits like a stick into a quiver. BD-1.7.3.4. - Ha nincz irod és ßelentzéd, miért teßed magad borbéllyá. - Having no ointment and box, why do you pose as hairdresser? BD-4.3.8.2.

Késö sötue. - It was baked too late. BD-1.1.3.5. - Kötue hüd komádat. Believe your friend with reservation only. BD-2.1.7.7. - Egy körtuély nem sok vgyan sok meduének. - One pear is not much for many bears. BD-5.6.6.10. Köz lónak túros az háta. - A common horse has scars on its back. BD-4.7.3.7. Sok lúd diznót gyöz. - Many geese overcome a pig. BD-1.4.2.9, 3.7.7.6., etc.

Meg sem fogtad saddîg mellyezted. - You did not yet catch, but already pluck it. BD-1.5.10.8. - Az minemü mosdót te énnékem tartaz, énis ollyan kendöt te néked. - Like the wash basin you offer me, like will be the towel I give you. BD-5.10.2.3. - Könyü tizenkét ökör vtán el tolni egy ßekeret. - It's easy to push a cart pulled by twelve oxen. BD-2.7.1.5. - Szomiú ökörnek zauaros vizis ió. - For a thirsty ox muddy water is also good. BD-3.6.3a.4.

Meg állani az sárt. - To stand the mud. (To be brave.) BD-3.8.3.4. - Igen talála az ßarua közöt az tölgyet. - He has hit the udder between the horns. (A big error.) BD-3.5.7.2. - Nincz oly rakot ßekér, kire egy velle ßéna fel nem fęr. - There is no packed cart that could not carry one more forkful of hay.) BD4.8.10.4. - Nem illet ßamárt veres nyereg. - A red saddle isn't fitting for an ass. BD-3.9.5.1.

El lopták az turbát, de had iárion, nálam az kúlcza. - The purse has been stolen, but let it go, its key is with me. BD-2.9.5.4. - Egy tiukmony sültîg meg lenne az. - It will be ready in a time an egg is baked. BD-3.6.7.1. - Kü ßöktek az felsö várból. - They have escaped from the upper castle (He lost his senses.) BD-1.8.7.3. - Az ki variat akar löni nem pengeti iját. - He who intends to shoot a crow does not bang his bow. BD-3.4.10.7. (Perturbas seram.) 


\section{REFERENCES}

At the end of each entry (in brackets) the meanings of the numbers following the letters in the in-text references are given.

AA = Arthaber, Augusto 1929. Dizionario comparato di proverbi e modi proverbiali italiani, latini, francesi, spagnoli, tedeschi, inglesi e greci antichi con relativi indici sistematico alfabetici. Ulrico Hoepli Editore, Milano 1929 (reprint 1952, 1972) 892 pp., 1483 sections (serial no.).

AJ = Aventinus, Johannes 1567. Johannis Aventini des Hochgelehrten weit berumbten Bayerischen Geschichtsschreibers Chronica Bavaria. Frankfurt a. M., CCCCXIIb $\rightarrow$ (WK)

AK = Adalberg, Samuel \& Krzyżanowski, Julian 1969-1978. Nowa księga przysłów i wyrażeń przysłówiowych polskich. I-IV. Państwowy Institut Wydawniczy, Warszawa. Tom I. A-J. 882 pp., Tom II. K-P. 1970. 1167 pp., Tom III. R-Ż. 1972.996 pp., Tom IV.: Wstęp. Bibliografia. Słównik wyrazów staropolskich, gwarowych i obcych. Indeks hasel pomocniczych (Stanisław Świrko - Dobrosława Świerczyńska). 1978. 632 pp. (vol.page/ serial no.)

BD = Baranyai Decsi János (Ioannes Decius Baronius) 1598. Adagiorvm Græcolatinovngaricorvm Chiliades quinque: Ex. Des. Erasmo, Hadriano Iunio, Ioanne Alaxandro, Cognato Gilberto, \& aliis optimis quibusque Parœmiographis ecerptæ, ac Vngaricis prouerbiis, quoad eius fieri potest, translatæ, studio ac opera succisiua Ioannis Decii Baronij. - Excudebat Iacobus Klöß, Bartphae, Anno 1598. (18)+1-127)+128-424+2 pp. (1.1.1.1 - 5.10.10.10 items). Reprint: ELTE Fontes ad Historiam Linguarum Populorumque Uralensium 5. Budapest 1978. Joseph Molnár (ed. \& foreword). (chilias.centuria.decas.serial no.)

BU = Bläsing, Uwe 1994. Tschuwaschische Sprichwörter und sprichwörtliche Redensarten. Harrasowitz Verlag, Wiesbaden. 849 pp. 4396 sections (serial no.).

CF = Čelakovský, František Ladislav. 1949. Mudrosloví národu slovanského ve př́slovich. Nakladatelství Vyšehrad, Prague. (1st edition in 1852), 892 pp. (page no.).

Er.Ad. = Erasmus Roterodamus, Desiderus 1574. Des. Erasmi Roterodami Adagiorum Chiliades quatvor cum sesquicentvria ex postrema authoris recognitione quibus præmissi sunt quatvor indices locupletissimi ... Ex Officina Episcopiana, per Eusebium Episcopum \& Nicolai Fr. hæredes, Basileæ MDLXXIIII. (116)+852+647+(86) pp. In the end it includes the collections of Hadrianus Iunius, Johannes Alexander Brassicanus, Johannes Ulpius, Gilbert Cousin/Cognatus, Ludovicus Cælius Rhodiginus, Polydorus Vergilius, etc. comprising 647 pages (chilias.centuria.serial no.).

FS = Franck, Sebastian 1541. Sprichwörter, Schöne, Weise, Herzliche Clugreden und Hoffsprüch. ... Beschriben ... Durch Sebastian Francken. Getruckt ... bey Christian Egenolffen. Franckenfurt am Meyn. 163, 211 fol. (fol.)

GK = Grigas, Kazys 1987. Patarliu paralelès. Lietuvi u patarlès su latvi u, baltarusiu,

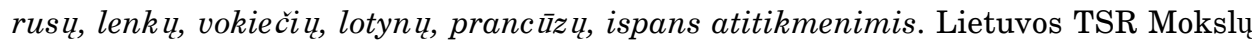
Akademija, Leidykla Vaga, Vilnius. 664 pp., 611 items (item).

HGF = Heltai Gáspár 1566. Szaz fabvla, Mellyeket Esopvsból, és egyęb ünnen egybe gyütet és ößve ßörzet, à fabuláknak ęrtelméuel egyetembe. (Heltai) Colosvarot. 244 fol. (RMNy-219). 
IN = Ikonomov, Nikolai Il (Икономов Николай Ил.) 1968. Балканска народна мъдрост. Успоредици на български сръбски турски румънски гръцки и албански пословици и поговорки. [Balkan folk wisdom. Bulgarian, Serb, Turkish, Romanian, Greek and Albanian proverbs and sayings] Изд. на българската акадмия на науките. София (Sofia). 364 pp. (2658 sections +555 Turkish proverbs used by the Turks in Bulgaria)(serial no.).

KI = Kniezsa István 1974. A magyar nyelv szláv jövevényszavai. I-II [The Slavonic loan words of the Hungarian language]. Akadémiai Kiadó, Budapest. I: 582 pp. - II: (Words of uncertain origin.) pp. 583-1044.

KM = Kuusi, Matti 1985. Proverbia Septentrionalia. 900 Balto-Finnic proverb types with Russian, Baltic, German and Scandinavian parallels. (FF Communications, no. 236) Suomalainen Tiedeakatemia, Helsinki. 451 pp. (900 sections)(serial no.).

KS = Krikmann, Arvo \& Sarv, Ingrid. Eesti Vanasõnad I-V. Kirjastus "Eesti Raamat", Tallinn. I. 1980. 911 pp.; II. 1983. 858 pp.; III. 1985.912 pp. (15,140 items); IV. Lisad. 1988. 530 pp. V:1. Эстонские пословицы. 1986. 400 pp.; V:2. Estnische Sprichwörter. 1987. 438 pp. (volume.serial no.).

ODEP = Wilson, F.P. 1970. The Oxford Dictionary of English Proverbs. Third edition. Oxford University Press, Oxford. 930 pp. (page/column).

PGy-1 = Paczolay Gyula 1987. A Comparative Dictionary of Hungarian-EstonianGerman-English-Finnish and Latin Proverbs with an Appendix in Cheremis and Zyryan. VEAB, Veszprém. 300 pp. Serial numbers: 1-624. (serial no.).

PGy-2 = Paczolay Gyula 1994. European, Far-Eastern and Some Asian Proverbs. A Comparison of European, Chinese, Korean, Japanese, Vietnamese and Other Asian Proverbs with English, German and Hungarian Equivalents. Central Library of the University of Veszprém, Veszprém. 200 pp. (section.chapter.serial no.) (Addenda: 1996, 8 pp.).

PGy-3 = Paczolay Gyula 1997. European Proverbs in 55 Languages with Equivalents in Arabic, Persian, Sanskrit, Chinese and Japanese. Veszprémi Nyomda, Veszprém. (Reprint: De Proverbio, Hobart 2002). 528 pp. 106 sections (number of section).

PGy-4 = Paczolay Gyula 1993-1994. Magyar közmondások és szólások nemzetközi rokonsága. [International affiliations of Hungarian proverbs.]. Acta Hungarica 4-5, 36-51. (1993-1994) (printed in 1997).

PGy-5 = Paczolay Gyula 2004. The first dated Hungarian and Polish proverb "Peel the lime tree until it peels" - "Addig hántsd a hársat, míg hámlik." - "Kiedy się łyka dra, wtenczas je drzyj” - In Kiedron, Stefan \& Kowalska-Szubert, Agata (ed.). Thesaurus polyglottus et flores quadrilingues. Festschrift für Stanislaw Prędota zum 60. Geburtstag. Oficyna Wydawnicza ATUT - Wrocławskie Wydawnictwo Oświatowe, Wroclaw. pp. 319-327.

PGy-6 = Paczolay Gyula 2000. Török rokonsággal (is) rendelkező magyar közmondások. [Hungarian proverbs affiliated to Turkish ones (among others).] In: Gazda József (ed.): Körösi Csoma Sándor és a magyarság keleti eredete. (Sándor Körösi Csoma and the Oriental origins of the Hungarians). Körösi Csoma Sándor Közművelődési Egyesület, Sepsiszentgyörgy. pp. 198-204. (page/ser. no)

PGy-7 = Paczolay Gyula 2000. János Baranyai Decsi and his Adagia. Acta Ethnographica Hungarica 45, 3-4. 271-294 (2000) and also in Barna-Stemler-Voigt (ed.): "Igniculi sapientiae" János Baranyai-Decsi-Festschrift, Országos Széchényi Könyvtár Osiris Kiadó, Budapest 2004. pp. 31-65. 
PGy-8 = Paczolay Gyula 2005. Universal, regional, sub-regional and local proverbs. Tautosakos darbai 30 [Folklore Communications], Vilnius, pp. 73-85.

PGy-9 = Paczolay Gyula (n.d.) The Adagia of János Baranyai Decsi. (Manuscript.)

$\mathbf{R D}=$ Düringsfeld, Ida von \& Reinsberg-Düringsfeld, Otto von. 1872, 1875. Sprich wörter der germanischen und romanischen Sprachen vergleichend zusammengestellt. Band I-II. Herman Fries, Leipzig. (Reprint: Georg Olms Verlag, Hildesheim - New York 1973) I. (XVI) + 552 pp. (960 items), II. (VIII)+638 pp. (765 sections+Nachtrag: $445-$ 519 pp.) (vol. ser. no.).

RL = Röhrich, Lutz. 1991 Das große Lexikon der sprichwörtlichen Redensarten. 1-3. Herder Verlag, Freiburg - Basel - Wien 1991. Band I. A-Ham. pp. 1-638., Band 2. Han-Sai. pp. 639-1274, Band 3. (1992) Sal-Z. pp. 1275-1910 (page/column).

ŚŚK = Świerczyńska, Dobrosława \& Świerczyński, Andrzej \& Kašètienè, Rasa 2000. Patarli ž Žodynas. "Tyto alba", Vilnius. 416 pp., 632 items (serial no.).

VG-1 = Vöö Gabriella 1989. Igaz ember igazat szól. Közmondások a romániai [erdélyi] magyar folklórból. [A true man tells the truth. Proverbs from the folklore of Hungarians in Transylvania, Romania.] Kriterion Könyvkiadó, București 1989. 316 pp. (5,662 types of proverbs.) (page/serial no., in brackets: frequency).

VG-2 = Vöö Gabriella 1999. Szaván fogjuk. Erdélyi magyar szólások. [We take you at your word. Hungarian sayings from Transylvania.] Erdélyi Gondolat Könyvkiadó, Székelyudvarhely. 372 pp. (page/serial no.).

WK = Wander, Karl Friedrich Wilhelm 1870. Deutsches Sprichwörterbuch. Band 2. (Gott-Lehren) Leipzig. (Reprint: Wissenschaftliche Buchgesellschaft, Darmstadt 1977). 1,884 columns (column 1655, serial number 89).

YM = Yurtbaş, Metin 1993. A dictionary of Turkish proverbs. Turkish Daily News, (Ankara). 654 pp. (page/column).

ZA = Záturecký, Adolf Peter 1975. Slovenské príslovia, porekadlá a úslovia . (Revised edition, Kosová, Mária (ed.), foreword Melicherčik, Andrej) (1st ed. Prague, 1897). Bratislava. 760 pp. (page/serial no). 